\title{
Assessment of the impact of Nigerian cultural values on professional code of media ethics
}

\author{
${ }^{1}$ Bo Daniel, Ph.D, ${ }^{2}$ Ugande Gabriel, Ph.D \\ ${ }^{1,2}$ Benue State University, Makurdi
}

\begin{abstract}
An intrinsic relationship exists among culture, a people and the media. This relationship is so profound that it exerts significant influence on the nature or shape of every society and its media. Over the years, what has been established is the fact that the media are not only influenced by cultural forces, they are indeed cultural institutions. That sort of relationship may sound so simplistic. The question therefore is whether culture and the media do conflict - how does culture interact with professionalism? There is therefore, the need to further define this relationship. Of particular concern here, however, is the question whether the professional character of Nigeria journalists is driven by cultural traits or by professional codes of ethics? Anchored on the functionalism theory, this study finds that there is a subsisting conflict between Nigeria culture and professional codes of ethics. As a result, the way Nigeria journalists carry out their professional duties is profoundly influenced by the Nigeria culture and largely unethical. The study recommends a structural balance that promotes culture but does not compromise professional ethics.
\end{abstract}

Key words: culture, media, code of ethics, professionalism

\section{Introduction}

Integrity is a media value that is clearly indispensable. Integrity generally is a value that is ascribed. It is therefore dependent on what the public holds to be its opinion or judgement regarding the general character of the media. Media integrity may therefore be treated as a subjective value that is bound by time and space. This explains why contrasting opinion often do exist regarding perceptions about the media. About the turn of the $19^{\text {th }}$ century media integrity dwindled, giving rise to what came to be known as yellow journalism. Public confidence weaned and the positive values of the media were at the risk of been eroded. Public dissent soared against the character of the media, sparking within it an urgent need for establishment of internal mechanisms of control. By the $20^{\text {th }}$ century various kinds of internal controls emerged, among them a media code of ethics.

While the code of ethics was expected to shape appropriate professional character, existing cultural values that naturally reflected the established way of life of the practitioners represented another strong source of influence. Culture, like ethics, embraces within it a mode of character. It seeks to provide a holistic approach that includes how a people behave in order to realize positive aspirations for development purposes. Often, it is unique to a group of people.

Like ethics, culture may have universal principles, those that deal with universal values of humanism, peace, democracy and human rights etc. Opitz in Okunna (2003:70) notes that the value systems that have given culture a universal character have led philosophers to the conclusion that there exists some similarity, in the moral codes adopted by the media in various countries of the world. It is also this reality that has led to the emergence of International Principles of Professional Ethics in journalism.

On such broad issues culture attracts a universal appeal but, there is also a conscientious value that defines the distinctiveness of each culture. As a result, the distinctive character, value and dignity of each culture are preserved by every group - a case of individualism in universality.

Production and consumption of media information require some synchronization, if the media must survive. The media must produce what is consumable. The media must not allow itself to be seen as estranged partner.

Indeed production is dependent on consumption because the value of information is determined by public opinion. Public opinion on the other hand is shaped by a critical understanding of ethical norms and a value system that is culturally relevant.

The symbolism of culture in enhancing the social value far beyond media consideration is expedient. Andrew Williams, while presenting a documentary on the construction of the fastest Roller Coaster in Abu Dhabi, on National Geographic Channel (2011), reaffirmed the influence of culture when in reference to the construction of train baskets (seats) he noted "cultural considerations had to be taken into account".

This influence exerted by culture is so profound that the quality of the media in society is shaped significantly by cultural norms. Consistent with this position is Nwabueze's (2010:151) thinking. He admits that the media is generally "influenced in one way or the other by cultural forces, aspirations and convictions that make up the society." This cultural influence is inevitable because as Okunna (2003:10) notes, as a child is born 
through the process of socialization the child "learns the norms and values of his or her culture ... these norms and values are incorporated into the individual's yardstick for judging human actions as good or bad".

These influences help to shape what our values are including our news values and perspectives. Sometimes, even the value ascribed to existing data and other experiences often end up been interpreted differently by people from diverse cultural backgrounds or perspectives. Cultural differences do also account for much of the pragmatism that defines the professional character of journalists - which codes of ethics they observe and which ones they compromise. What questions to ask and how; which clothes to wear; which stories to write including which events to cover and slant to adopt, etc, all do have cultural relevance. It is this cultural reality that led MacBride et al. (1981:36) to the following conclusion: "news values differ from one country to another and from culture to culture ..."

The characteristic simplicity with which these cultural pressures are treated however, appear to underestimate the impact of culture in shaping the influences that affect the professional behaviour of journalists. This position is justified by Okunna (2003). According to her, mass media practice does not only work in conjunction with other social institutions, how it is practiced, the observation of its code of ethics is a reflection of the values of the society in which it operates. The society, on the other hand is guided by patterns of behaviour that have become a way of life or culture of the people.

Generally, ethical decisions may not have socio economic and political value if they do not subscribe to or service the aspirations of a people. Ethical codes dealing with concepts like truth, fairness, etc, are culturally value specific. For instance, the idea that there is subjectivity even in objectivity is driven by the fact that cultural experiences, which have shaped a person's way of life generally, affect how one interpret issues, including his interpretation of ethical concerns or concepts. This is the point expressed by Surlin (1987): "Moral, ethically or socially responsible behaviour, or a lack thereof, by a mass media professional undoubtedly reflects one's personal value system".

\section{The dichotomy between culture and professional ethics}

Studies about the character of the Nigerian media (Bo, 2012; Bo, 2006; Soola, 1996; Odomu, 2005; etc) suggests that violation of media ethics is common among practicing journalists in the country. According to Odomu (2005) the codes violated by journalists include receiving gifts or gratification. In his research findings, Soola (1996) concluded that Nigerian journalists have failed to enthrone themselves as professionals that revered professional ethics. What these researches failed to enlist are the various influences that drive these violations.

Clearly culture is seen as encompassing the totality of human behaviour, life style, values and value system, customs, beliefs, and a general behaviour pattern that shapes a particular society. It is the way of life of a people, group or society. This way of life encompasses how the people think, act, what they cherish or dislike, what they wish to be associated with or strive to achieve; generally, what their value systems are. Nwabueze (2007) may have shared this position when he defined culture as the entirety of norms, values, belief systems and life patterns that give a group of people an identity.

Similarly, Mbagwu's definition quoted by Nwabueze in Wilson (2010: 153) and Bodley's definition in Encarta Encyclopaedia (2009) see culture as referring to patterns of behaviour and thinking that people living in a social group learn, create and share.

The eight Principle of the International Principles of Professional Ethics in Journalism states: "A true journalist stands for the universal values of humanism, above all peace, democracy, human rights, social progress and national liberation, while respecting the distinctive character, value and dignity of each culture, as well as the right of each people freely to choose and develop its political, social, economic and cultural systems ...." The liberties granted the journalist to respect "the distinct character ... of each culture" and the "right of each people freely to choose and develop its ... cultural systems" presents a potential source of conflict between media ethics and cultural values. This conflict is inevitable because international spheres and distinctive cultural values often conflict based primarily on variations or differences in history, geography and aspirations.

Media ethics weave around Kantian principles and universal values that are beyond geography. As Patterson and Wilkins (2002: 2) notes media ethics is build on the maxim "this is the action that can be rationally justified", while culture survives on the maxim 'this is how we do it here'.

Culture occupies a prime position that drives thoughts and actions of a group of people. The value system of any given society plays either a positive or negative role in determining how the media comply with professional ethics meant to guide professional practice. In order words, as noted by Nwabueze (2010:499) "cultural values and journalism ethics are constantly at war". This is because the value system of a society exerts pressure on a journalist to the extent that where such values are inconsistent with professional ethics, they could possibly cause the reporter to operate unethically.

That is why Mfumbusa (2008:140) is of the opinion that in Africa media professionals "operate in a context marked by the politics and culture of the larger society that are essentially dishonest and corrupt." The 
primary influence of culture on the operations of professional journalists is also acknowledged by Okunna (2003) who admits that since journalists operate in a society that is defined by a way of life, they are bound to be influenced by its way of doing things, irrespective of what their professional guiding principles may be.

Studies on media ethics in Nigeria agree, for instance, that gratification is one of the codes of ethics that is abused by practicing journalists. The western notion of gratification is very broad. It is a situation where a journalist receives gift or freebies from news sources in the course of performing his/her professional duties. In this context, a journalist who visits a source as part of investigation or to conduct interview, must not receive any gift in cash or kind or have any of his services, needs, wants, etc, paid for by the source.

Infringement or violation of this code does not acknowledge motive of the giver or receiver as justifiable. Motive is inconsequential, no matter how noble. The basic assumption is that gift or freebies create a psychological impact on human behaviour that could induce compromise.

Under the African cum Nigerian cultures there is a communal approach to life. The individualistic approach of journalism is sometimes at variance with the African notions of good and bad behaviour; the good person and the bad person. This is particularly imperative because journalism first of all serve the society in which it is practiced, and then severs the world at large.

\section{Conflict between Codes of professional ethics and Cultural values}

Gratification: Gratification forbids journalists from receiving gifts or freebies from sources. The tradition or cultural settings of some Nigerian societies however, provide a different perspective to gift and freebies. In the Ibo culture, for instance, it is customary for a host to present Cola nut and or Palm wine to his guest or visitor.

This cultural event is certainly not without a motive. It is intended to symbolise expression of peace and welcome and to receive love not hurt or injury. A similar culture exists among the Yoruba people of South West Nigeria. Like the Ibos, they also present their guests or visitors with Cola nut. These are forms of gifts which gratification abhors.

Accuracy and fairness: The code on Accuracy and Fairness provides that journalist should be fair, balanced and accurate. They must not take sides or by driven by any sentiments. Cultural values are however not always driven by impartiality. Some demand specific loyalties and sentiments. For instance, among the Tiv people of Central Nigeria, there is the proverb zenda tsough man uhide $u$ kam wan kyegh tyough (first chase away the Hawk before you admonish the Chick). The Ukwuani speaking people of Delta State of South-South part of Nigeria, also have the same proverb: "Bu uzo chufu uko iba do nnwa okuku eka ni nti (first chase the hawk away before warning the chick against loitering in the open). The cultural mandate here is that a journalist under this cultural sphere needs to compromise neutrality, fairness and objectivity in reporting, for instance, a conflict between his relations or kinsman and strangers.

Objectivity: Among the Ibibio people of Akwa Ibom State, there is the adage Ukot, eyen-yen, iman (it is ones duty to protect the interests of his in-laws and grandchild). It is an abomination to harm them or their interests.

What this implies is that a journalist is forbidden to report, for instance, the level of involvement of his in-laws in a crime or dispute, particularly if such report may expose them to prosecution or to suffer any other injuries including damaged reputation.

In the Ibo, Igala, Idoma and some other cultures, during some specific cultural celebrations masquerade have a cultural legitimacy to violate the rights of individuals, including women and children, through torture or even death, where such individuals are deemed to have violated some rites. When that occurs such incident would not attract negative report, culturally. The journalist would report in a way that conceals such violations.

Truth/Factual reporting: Media code of ethics crowns truth as the cornerstone of journalism. Truth and fact must however complement each other for media messages to have meaning. Media codes do ensure that media messages are not misleading or inaccurate. Among the Idoma people of Central Nigeria, when their paramount leader dies he is said to have gone hunting. A reporter bound by this cultural history would at best suppress information about the death of his Monarch; at worst he would provide a misleading story that would also not be factual. An even deeper concern is the tendency by this cultural reality to promote falsehood as a virtue, consciously or unconsciously.

Generally, African and indeed Nigerian cultures believe there is a constant struggle between the good and bad people and spirits. The community has a responsibility to change the bad people into good people. As a result people are repeatedly counselled over misdeeds; a luxury that is alien to journalists under the western media traditions (code of ethics). Under the cultural traditions, community members are ostracized or visited with severe sanctions if they continued to engage in persistent misbehaviour after repeated efforts by the community to correct the wrongdoer have failed. The community gives up and ostracizes the person from their fold in order to preserve its wellbeing and community harmony. 


\section{Statement of problem}

The debate concerning media ethics has intensified in recent years, fuelled mainly by the dwindling standards of media practices. The role of practitioners has taken centre-stage as concerns over what constitutes ethical and therefore socially acceptable practice and behaviour, by the journalists, continues to attract attention. Researchers (Soola: 1996, Odomu: 2005, etc) have acknowledged that Nigerian journalists do violate code of media ethics. Although some reasons have been advanced for these violation including lack of knowledge of ethics (Soola: 1996) and poor salaries (Odomu: 2005), there is also the need to take a look at the cultural context as well. That is exactly our concern in this study - how existing cultural norms influence ethical violation among Nigerian journalists.

Basically, the relationship between culture and the media is treated in its very simplistic form - one of transmitting culture. The debate overemphasizes the positive effect, perhaps, overlooking the fact that there may be a negative effect as well. The mass media is seen as representing western-style culture. The result is that although other regions of the world have adopted the western communication systems, the debate rages on regarding the holistic compatibility of its code of ethics with the cultures or way of life of the people. Africa, for example, presents in some cases distinct cultural classifications that do not agree with universal ethical modes set for the media.

In this context, when acts only serve to propagate or satisfy pursuits of individuals, they are not regarded to be as good as those that serve the family, clan or tribe. They may be regarded as bad acts if they are harmful to the family, clan or tribe. For this reason, the more beneficial to a larger community the acts are, the more ethically acceptable they are. Thus the positive value of acts is not necessarily measured based on lack of harm but who suffers the injury. That is why public office holders for instance, who corruptly enrich themselves are honoured by their communities.

In some communities, even armed robbers would be tolerated as long as they don't carry out their nefarious activities in their communities. Such people sometimes do receive protection, which explains why there exists cases where wanted criminals, do sometimes, find safe haven in their communities.

The question therefore, is whether the basic principles upon which journalists practice their profession are not compromised due to cultural influences or distinct cultural values. In Nigeria questions are been asked whether the way journalists practice their profession is not influenced more by cultural values than professional codes of journalistic practice. In other words do cultural realities not influence the ability of the journalist to adhere to professional media ethics? And that is what this study investigates.

\section{Research Objectives}

The research has the following objectives:

To establish whether cultural values do affect the way journalists adhere to professional ethics.

To find out the reasons that encourage the journalists' behaviour, in relation to culture and media ethics.

\section{Research Questions}

Are journalists equipped to resist influence of culture in the course of their professional practice? How do cultural values affect the way journalists adhere to code of ethics for the media? What cultural and ethical mechanisms drive compliance among Nigerian journalists?

\section{Theoretical framework}

Murdock and Golding (2005) hold the view that mutual interdependence exists between the media and culture. This view sees the media as an institution for the transmission of culture. If the mass media serve as channels for transmission of culture then journalists are the agents that pollinate culture and media practice. This relationship reinforces interactionality and mutual interdependence as defined by the functionalist theory, which provides the basic framework upon which the study is anchored.

Udoaka (2007) asserts the relevance of the theory by describing society as an organism made up of a system of interdependent parts, which work together for the survival of the whole. This interdependence helps to safeguard the value of both culture and the media as vehicles for entertainment, education and information, among other functions.

\section{Methodology}

The study adopted survey method of research. Respondents were purposively selected to reflect different cultural backgrounds. Consequently, journalists with adequate knowledge of selected ethnic groups were purposively selected. The ethnic groups are: Yoruba, Tiv, Ibo, Ibibio, Idoma, Hausa/Fulani, and the Ukwuani people of Delta State. The study therefore focused principally on the influence the cultures of these nationalities have on journalists. 
A total of 350 questionnaires were distributed using the purposive sampling technique. This was because the questionnaire had to be distributed to journalists with adequate knowledge of the cultures adopted for study. Although in few cases journalists who are not nationalities of the selected cultures but who have deep knowledge of the said cultures due to long period of contact and cohabitation were also sampled. Sampling was therefore done in the following selected cities/towns: Makurdi, Enugu, Lagos, Kano, Uyo and Asaba.

Out of a total of 350 questionnaires that were distributed, 270 representing $77 \%$ were returned. The difficult task was trying to locate journalists with the relevant cultural backgrounds. Although the researchers employed the use of research assistants it was still a big challenge. There are also some methodological challenges, as sometimes respondents may, for instance, be unwilling to expose the truth, as observed in Mireya Marquez Ramirez (2005) research on journalistic bribery in Mexico. She had to turn the tape recorder off to get journalists to talk openly about bribery and admit their own involvement in it.

Similar problems of respondents' dishonesty exist for surveys as well. According to Skjendal (2010: 377) "even if responses are given anonymously, respondents tend to express what they perceive as being the most 'correct' answer." Despite the limitations, the survey method is adopted because as Barran (2002: 408); Ohaja (2003: 11); Wimmer and Dominic (2000: 161), note it provides the necessary scientific tools for finding, describing and interpreting existing phenomena. Barran (2002: 408) specifically elaborates further: "surveys allow mass communication researchers to measure characteristics, opinions, or behaviour of a population by studying a small sample from that group."

\section{Data Presentation and Analysis.}

The Table below (Table I) seeks to take a look at the demands of some Nigerian cultures on the Nigerian journalists. Findings indicate that rather than report a story in which a relation (kith and kin) of a journalist was involved it would be culturally expedient for the journalist not to report the event in order not to compromise the interest of the relation.

Table 1: Cultural demand on stories that would compromise your kith and kin?

\begin{tabular}{|c|c|c|c|c|c|c|c|c|}
\hline Item & $\frac{\pi}{Z}$ & 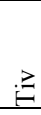 & $\frac{0}{0}$ & $\begin{array}{l}\mathbb{Z} \\
\mathbb{0} \\
\mathbb{Z} \\
\end{array}$ & 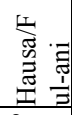 & 离 & 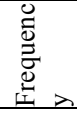 & 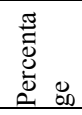 \\
\hline To report objectively & 6 & 8 & 5 & 3 & 2 & 7 & 31 & $11.4 \%$ \\
\hline $\begin{array}{l}\text { To leave out the facts that compromise } \\
\text { my kit and kin }\end{array}$ & 9 & 8 & 7 & 10 & 6 & 5 & 45 & $17 \%$ \\
\hline $\begin{array}{l}\text { To inform some elders of the community } \\
\text { on the relation's involvement }\end{array}$ & 8 & 6 & 10 & 11 & 9 & 8 & 52 & $19.2 \%$ \\
\hline $\begin{array}{l}\text { To distort the report in order to protect } \\
\text { his/her interest }\end{array}$ & 5 & 4 & 5 & 6 & 4 & 7 & 31 & $11.4 \%$ \\
\hline Not to report the story & 12 & 9 & 11 & 8 & 15 & 14 & 69 & $26 \%$ \\
\hline There are no cultural demands & 5 & 10 & 7 & 7 & 9 & 4 & 42 & $16 \%$ \\
\hline Total & 45 & 45 & 45 & 45 & 45 & 45 & 270 & $100 \%$ \\
\hline
\end{tabular}

Specifically, 69 or $25.5 \%$ of respondents admit that by the norms of their cultures they would rather not report on a story which would compromise the interest of their kith and kin. Another 45 representing $16.6 \%$ also said if they must report on such events they would have to leave out the aspects or facts that would compromise the interest of their relation, while $19.2 \%$ or a total of 52 of the respondents said another alternative they have is to report the involvement of their relation to elders available. However, 31 respondents representing $11.4 \%$ are of the opinion that they are at liberty to report such a story as objectively as ethically expedient. Only a total of 31 or $11.4 \%$ of respondents said they may even have to distort the story if that were necessary to safeguard the interest of their relation, while an even smaller number of respondents 14 representing only $5 \%$ said they are not aware of any cultural demands on them that require compromising media ethics in order to protect the interest of a blood relation.

The units of analysis across the cultures however, reflect variations. The result shows that among the Yoruba, Ibibio, Hausa/Fulani and Ukwuani cultures the highest number of respondents said they are required rather not report a story in which their kith and kin would be compromised. Among the Tiv people the cultural demand is not significant. While among the Idoma culture reporters are expected, as a priority, to informally inform elders who may be available.

None of the cultures expects the journalists to adopt the required professional attitude in reporting on a story that would compromise his kith and kin.

What the findings reveal is the strength of cultural norms on the perception of the journalist towards his professional ethical balance. As indicated in the Table a whopping $72.7 \%$ of the respondents have conceded to doing what would not hurt their relation as part of their obligation to their cultures. 


\section{Communal responses to infringement on cultural norms}

In Table II, the research sought to find out the kind of social response that a journalist would be exposed to should he/she conform to ethics at the expense of the interest of his/her relation. The overwhelming position is that journalists who insists on following professional ethics where doing so would compromise the interest of their relations will face disapproval from their kinsmen.

Table II: What would happen if you report the story objectively?

\begin{tabular}{|c|c|c|c|c|c|c|c|c|}
\hline Item & 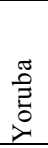 & : & $\begin{array}{l}\frac{0}{2} \\
0 \\
0\end{array}$ & $\begin{array}{l}\tilde{\Xi} \\
\tilde{O} \\
\end{array}$ & 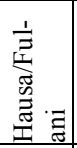 & 竝 & 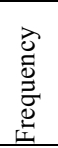 & 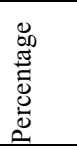 \\
\hline $\begin{array}{l}\text { I will receive commendation from my } \\
\text { community }\end{array}$ & 7 & 9 & 8 & 5 & 4 & 5 & 38 & $14 \%$ \\
\hline $\begin{array}{l}\text { It will enhance the reputation of my family } \\
\text { members }\end{array}$ & 8 & 7 & 7 & 3 & 5 & 6 & 36 & $13.3 \%$ \\
\hline I will be treated as a deviant & 14 & 12 & 13 & 18 & 21 & 15 & 93 & $34.4 \%$ \\
\hline $\begin{array}{l}\text { The action would be counted as an act against } \\
\text { community values }\end{array}$ & 12 & 13 & 15 & 18 & 15 & 16 & 89 & $33 \%$ \\
\hline No action will be taken & 4 & 4 & 2 & 1 & - & 3 & 14 & $0.1 \%$ \\
\hline Total & 45 & 45 & 45 & 45 & 45 & 45 & 270 & $100 \%$ \\
\hline
\end{tabular}

As a result, an overwhelming majority of 93 representing $34.4 \%$ of respondents admit that journalists who would rather preserve professional ethics and present objective reports that compromise the interests of their kinsmen are treated as deviants by their communities. Another 89 or $32.9 \%$ also said a journalist who does so would be seen as acting against the established values of the community. A total of 36 respondents representing $13.3 \%$, are however, of the opinion that a journalists who acts professionally and ethically and by doing so violates the interests of his kinsmen and to that extent the cultural norm of his/her community would have enhanced the reputation of his/her family. The lesser number of 38 or $14 \%$ of the respondents also said a journalist who goes against the interests of his kinsmen in order to protect professional ethics will receive commendation from his community. The least number of 14 representing $0.1 \%$ of respondents believe that no actions would be taken against such a journalist.

Analyses across cultures show that the Tiv, Ibibio and Ukwuani cultures view reports that compromise their kith and kin as a communal matter, while Yoruba and Hausa/Fulani would most readily treat it as deviant individual behaviour. Generally however, a total of $67.3 \%$ of respondents see such reports as unacceptable.

What this suggests is that established norms of a people, their cultural values are cherished and control systems put in place for their preservation. Generally, the punishment and reward systems under a cultural environment are particularly unique, and sometimes, far reaching.

\section{Cultural safeguards}

Findings in Table III have led to the conclusion that some forms of social sanctions have been adopted by various communities as a system of preserving existing cultures. Some of the sanctions exist in the form of expressions of social discontent. It is for this reason, for instance, that majority 119 or $44 \%$ of respondents admit that there are sanctions against violation of cultural values for which defiant members of the community are held liable.

Table III: What practical measures, if any, exist as a way of ensuring conformity with cultural norms in your

\begin{tabular}{|c|c|c|c|c|c|c|c|c|}
\hline \multicolumn{9}{|c|}{ community? } \\
\hline Item & 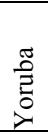 & 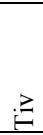 & $\begin{array}{l}. \\
0 \\
0\end{array}$ & 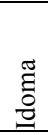 & 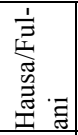 & 离 & 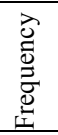 & 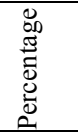 \\
\hline There are sanctions for violators & 22 & 20 & 17 & 21 & 20 & 19 & 119 & 44 \\
\hline $\begin{array}{l}\text { Some sanctions exist for both violators and their family } \\
\text { members }\end{array}$ & 13 & 19 & 21 & 20 & 18 & 19 & 110 & 40.7 \\
\hline No punishment is meted out to the violators & 4 & 5 & - & - & 3 & 2 & 14 & 5.1 \\
\hline Violations are not given serious consideration & 6 & 1 & 7 & 4 & 4 & 5 & 27 & 10 \\
\hline Total & 45 & 45 & 45 & 45 & 45 & 45 & 270 & $100 \%$ \\
\hline
\end{tabular}

The second highest figure of 110 representing $40.7 \%$ of total respondents said in some cases existing social sanction which violation of cultural norms attract may affect a whole family where a member has committed the violation. A total of 14 or $5.1 \%$ of respondents admit that no punishment is usually meted out to members of the community who may violate cultural norms meant to preserve the individual and collective 
integrity of the community, while a lesser number of 27 or $10 \%$ are of the opinion that although violation do occur, they are not given any serious attention as to warrant sanctioning the culprits.

There is generally overwhelming acceptance that in all the cultures there exists sanctions against violation of their cultural norms. This position has recorded a total of $84.7 \%$. although not statistically significant, there are slight differences in emphasis in responses on particular units of analyses. The Ibibio and the Idoma cultures have shown a stronger indication that violations, sometimes, have far reaching consequences that transcend individuality and affect the family as a unit.

The point to note here is that in Nigeria cultures the influence of the community, particularly the family, is often acknowledged and sometimes taken into account when as Kasoma (2010: 13) notes "apportioning blame to a person for his or her bad behavior". Specifically, some personal acts are attributed to the family influence or background, an indication or believe that a family with bad people usually begets illmannered children and that a good family begets well-behaved people.

The adoption of this stick approach is particularly instructive as a means of enforcing compliance to existing cultural norms for the sustenance of social values. This findings does seem to explain why sometimes some families are denied favours or even positions on account of the action of another member of the family.

\section{Media ethics and the question of sanctions}

The information sought in Table IV seeks to establish if there is a strong consciousness about the existence of sanctions and its applicability for violations of professional media ethics. The dominant opinion is that journalists are aware of the existence of sanction for violations of media ethics. Its application is however limited to individual violators.

Table IV: What Practical measures, if any, exist as a way of ensuring conformity with professional media

\begin{tabular}{|c|c|c|c|c|c|c|c|c|}
\hline \multicolumn{9}{|c|}{ ethics? } \\
\hline Item & 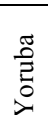 & 主 & $\frac{0}{0}$ & $\begin{array}{l}\mathbb{Z} \\
\stackrel{0}{0}\end{array}$ & 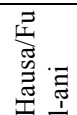 & 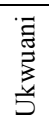 & 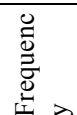 & 离 \\
\hline There are sanctions for violators & 17 & 20 & 19 & 18 & 16 & 17 & 107 & $37 \%$ \\
\hline $\begin{array}{l}\text { Some sanctions exist for both violators and their } \\
\text { family members }\end{array}$ & - & - & - & - & - & - & - & - \\
\hline No punishment is meted out to the violators & 17 & 19 & 16 & 19 & 15 & 14 & 100 & $37 \%$ \\
\hline Violations are not given serious consideration & 11 & 6 & 10 & 8 & 14 & 14 & 63 & $23.3 \%$ \\
\hline Total & 45 & 45 & 45 & 45 & 45 & 45 & 270 & $100 \%$ \\
\hline
\end{tabular}

Specifically, a total of 107 or $39.6 \%$ of respondents admit to the existence of sanctions against journalists who violate codes of media ethics. A total 100 or $37 \%$ are of the opinion that violations do not attract any punitive measures, while 63 respondents representing $23.3 \%$ said violations of code of ethics are not given serious considerations. No evidence exists to suggest that in some cases family members of violators do suffer the consequences as well.

This result reflects the distinctive character between western approach to systems of control and the traditional or cultural approaches. While western approaches emphasis individualism, the cultural or traditional approaches may have communal effect. That explains why culturally, the violation of cultural norms by an individual may, in some cases, impact on the whole family.

The question of application of sanctions for violations of code of ethics is generally loose and ineffective. That neutralizes the fact of their existence, and compromises their value.

\section{Sanctions as instrument of control}

There is also the question whether enforcement of sanction for violation of media ethics is more pronounced than enforcement of sanctions against violation of cultural norms. This is addressed in Table V. The findings show why journalists would rather comply with their cultural norms than media ethics. A total of 126 respondents representing $46.6 \%$ list violation of cultural norms as attracting more sanctions than violation of codes of media ethics. 
Table V: Between violation of media code of ethics and violation of cultural norms, which one, in your opinion, Most effectively apply sanctions?

\begin{tabular}{|c|c|c|c|c|c|c|c|c|}
\hline Item & $\begin{array}{l}\tilde{0} \\
\vec{\partial} \\
0\end{array}$ & $\gtreqless$ & 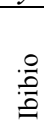 & $\begin{array}{l}\text { : } \\
\stackrel{0}{0} \\
\end{array}$ & 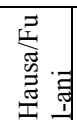 & 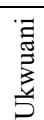 & 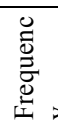 & 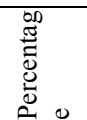 \\
\hline Violation of media code of ethics & 8 & 7 & 10 & 9 & 6 & 6 & $\overline{46}$ & $17 \%$ \\
\hline Violation of cultural values & 20 & 21 & 19 & 25 & 21 & 20 & 126 & $46.6 \%$ \\
\hline They attract Same level of sanctions & 8 & 7 & 9 & 5 & 9 & 8 & 46 & $17 \%$ \\
\hline $\begin{array}{l}\text { Violation of either code of media ethics or cultural } \\
\text { norms don't attract any serious sanctions }\end{array}$ & 9 & 10 & 7 & 6 & 9 & 11 & 52 & $19.2 \%$ \\
\hline Total & 45 & 45 & 45 & 45 & 45 & 45 & 270 & $100 \%$ \\
\hline
\end{tabular}

A fewer number of respondents 46 or $17 \%$ believe that there is more seriousness in enforcing sanctions against violations of media ethics than violation of cultural norms. A similar number 46 or $17 \%$ of the respondents agree that violations of both code of ethics and cultural norms do receive the same rate of sanctions. Another 52 or $19.2 \%$, which is the least number of respondents believe that violation of either media code of ethics or cultural norms don't attract any serious sanctions.

The implication of this data does seem to be that cultural issues have occupied a more central place in the lives of the people; generally, irrespective of class and other social distinctions. As a result, violations are more easily noticeable and their effects on social harmony taken more seriously. That seems to explain why their violations are more frequently sanctioned.

\section{Conformity to cultural norms/media ethics}

The following Table VI seeks to establish if journalists conform more to cultural norms than media ethics. As the result indicates there is an overwhelming consensus that journalists respect the norms of their cultures than they do to media code of ethics.

Table VI: Journalists do conform more to cultural norms than media code of ethics

\begin{tabular}{|c|c|c|c|c|c|c|c|c|}
\hline Item & 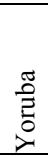 & 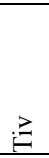 & $\begin{array}{l}. \\
? \\
0\end{array}$ & 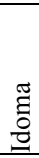 & 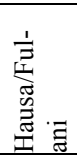 & 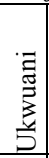 & 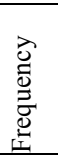 & 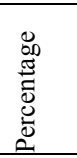 \\
\hline Strongly Agree & 17 & 16 & 19 & 18 & 16 & $\begin{array}{l}2 \\
0 \\
\end{array}$ & 106 & 39.2 \\
\hline Agree & 19 & 21 & 19 & 20 & 19 & $\begin{array}{l}1 \\
6 \\
\end{array}$ & 114 & 42.2 \\
\hline Disagree & 3 & 4 & 4 & 3 & 4 & 5 & 23 & 8.5 \\
\hline Strongly Disagree & 6 & 4 & 3 & 4 & 6 & 4 & 27 & 10 \\
\hline Total & 45 & 45 & 45 & 45 & 45 & $\begin{array}{l}4 \\
5 \\
\end{array}$ & 270 & $100 \%$ \\
\hline
\end{tabular}

That general consensus is drawn from the fact that a total of 106 representing $39.2 \%$ strongly agree with the proposition that journalists do conform more to cultural norms while another 114 or $42.2 \%$ which is the highest number said they agree. A total of 23 or $8.5 \%$ said they disagree while 27 or $10 \%$ said they strongly disagree.

Clearly, the position of those who believe journalists do conform more to cultural norms is overwhelming. As indicated, a total of $81.4 \%$ agree with the proposition while only $9.5 \%$ said they disagree. The reason could be the communal impact that some cultural issues including violations have on the larger cultural/traditional community and their values.

\section{Knowledge level on cultural issues and media code of ethics}

In Table VII, the question is asked concerning the level of awareness journalists have on cultural issues or norms and their knowledge level on media codes of ethics. The result suggests that journalists are more aware of cultural issues of their communities than they are of the codes that define their professional practice. That explains why only a total of 22 representing $8.1 \%$ of respondents said there is no difference in their awareness of the demands of their cultures and the demands of media codes of ethics. 
Table VII: Journalists knowledge level of media code of ethics and cultural norms

\begin{tabular}{|c|c|c|c|c|c|c|c|c|}
\hline Item & 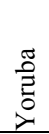 & $\stackrel{\gtrless}{E}$ & $\frac{\circ}{2}$ & 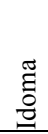 & 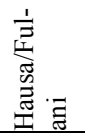 & $\frac{\sqrt[J]{J}}{3}$ & 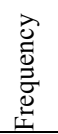 & 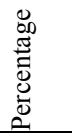 \\
\hline $\begin{array}{l}\text { Very conversant with cultural norms of my } \\
\text { community }\end{array}$ & 17 & 16 & 18 & 20 & 19 & 15 & 105 & 38.8 \\
\hline Average knowledge on cultural issues & 5 & 6 & 6 & 7 & 3 & 5 & 32 & 11.8 \\
\hline Very conversant with codes of ethics & 10 & 9 & 12 & 8 & 10 & 11 & 60 & 22.2 \\
\hline Average knowledge on codes of ethics & 10 & 9 & 6 & 5 & 9 & 12 & 51 & 18.8 \\
\hline $\begin{array}{l}\text { No difference in my knowledge on culture and } \\
\text { codes of ethics }\end{array}$ & 3 & 5 & 3 & 5 & 4 & 2 & 22 & 8.1 \\
\hline Total & 45 & 45 & 45 & 45 & 45 & 45 & 270 & $100 \%$ \\
\hline
\end{tabular}

Another 32 or $11.8 \%$ said the knowledge they have on issues of their cultures is at best average, while a total of 105 representing $38.8 \%$ said they are very conversant with cultural issues of their communities. A total of 60 or $22.2 \%$ said they are very conversant with the codes of ethics that guide their professional practice.

The findings here suggest agreement with earlier findings indicating that journalists conform more to cultural norms than media code of ethics. While, for instance, a total of $61 \%$ of the respondents disagree with the opinion that journalists conform more to code of media ethics. Only a total of $39 \%$ expressed the opinion that the journalists do conform more to media code of ethics. The reason appears to be because they have more knowledge of the cultural norms.

These findings do also suggest that cultural bonds, which have become a way of life, have stronger influence on the journalist's personality. In democratic societies these influences are profound because the value of a strong link between the journalist and his community and culture could be the key to the journalist's future ambitions.

\section{Conclusion}

The question of relationship between media code of ethics and cultural norms are inherently conflictual. One primarily sets the standards for western officialdom, while the other is driven by a way of life that reflects peoples' historical patterns involving tradition and communal aspirations. For instance, while in the African life bad people in a community are rather advised and counselled so that they may become better members of the community, the media would simply condemn, criticise and ostracise.

Most cultural values predate western communication systems. They have been with the people as a way of life that is designed to maintain harmony and obedience to communal values and aspirations. To ensure the preservation of traditional societies, violations of socio communal values sometimes attract sanctions that go beyond individual violators. This reflects acknowledgement of African notion of communal or family bonds and ties as well as a system of checks.

The media code of ethics, on the other hand provides a slow and sometimes ineffective system of sanctioning violators. The result is the existence of journalists who feel a more compelling need, even more secure complying with their cultural norms than media ethics.

The reality too is that all the cultures attach a common value to issue of culture. Nigerian cultures are seen as a way or preserving the people's heritage and for ensuring harmony, unity and progress, all of which are viewed from a communal perspective. It is this position that may have driven Kasoma (2010) notion of a "journalism with a human face" and what he call "individualism and divisionism", which today permeate African journalism.

\section{Recommendations}

Preservation of cultural norms is a value that must be preserved, it is therefore recommended that the principle of Aristotle's Golden Mean be applied where cultural norms and media ethics conflict.

There is need to redefine media codes of ethics on principles that bring contextual relevance to ways of life of African societies rather than continue to imitate the ethical precepts of the western world.

Culture, like language grows and assimilates, there is the need for the Nigerian journalists to abandon cultural values that compromise basic ethical values like objectivity, fairness, balance and truth.

There is the need to practice journalism in a way that maintains the African ethical roots but which at the same time reasonably retains the global appeal on common values. In other words there is no need to discard mutual counselling and correction of Nigerian communal living for a selfish and self centred approach of western styled journalism. 


\section{References}

[1]. Aiyetan, D. (2002, May 6). Corruption in the media. Tell magazine, p.32

[2]. Baran, S.J. \& Davis, D.K. (2003), Mass Communication Theory: Foundations, Ferment, and Future. Belmont: Wadsworth/Thomas Learning.

[3]. Bittner, John (1989). Mass communication: An introduction, Englewood Cliffs, New Jersey: Prentice Hall.

[4]. Bo, D. (2006). Ethical Issues in Nigerian Media: Revisiting the 1964/65 Elections, Mass media review: An introductory journal of mass communication, Vol. 1, No 2. P 48-61

[5]. Bo, D. (2012). Assessment of Ethical Practices in Nigerian Journalism. Unpublished PhD Thesis. Department of Mass Communication, Benue State University, Makurdi.

[6]. Bodley, J.H. (2009), "Culture.” Microsoft Encarta. Redmond WA: Microsoft Corporation Gemstone, 2025 Nigeria (2009). Value system. http://www.gemstone2025.or.Retrieved23-10-09

[7]. Learning Commons (2009). What is culture? Values and beliefs as components of culture. http://www.wsu.edu/gened/learnmodules.retrieved 25-10-09

[8]. MacBride S. Et al (1981). Many voices, One world, Ibadan: Ibadan University Press.

[9]. Mbiti, John S. (1975). An Introduction to African Religion. London: Heinemann.

[10]. Mfumbusa, B.F. (2008). Newsroom ethics in africa: quest for a normative framework. Africa communication research. 1.(2). September, 139-157

[11]. Murdock, G.K \& Golding, P. (2005). Culture, communication and political economy. In J.

[12]. Curran, \& M. Gurevitch (eds), mass media and society, $4^{\text {th }}$ edition. London: Hodder Education, Pp. 60-83.

[13]. Nwabueze, C. (2006). The art of investigative reporting: A practical guide. Enugu: Daisy Press.

[14]. Nwabueze, C. (2010). Brown envelopes and the need for ethical reorientation: Perceptions of Nigerian journalists. African Communication Research,Vol. 3, No. 3, Pp 497-521.

[15]. Nwabueze, C. (2010), Value System, News Values and Journalism Ethics: The Nigerian Experience. In Wilson, D. (2010), Perspectives on Communication and Culture. Uyo:

[16]. African Council for Communication Education (Nigerian chapter).

[17]. Odumu, A.A. (2005) A Study of Unethical Practices Among Journalists in Selected Media Houses in Plateau State. Master of Arts Thesis. University of Jos.

[18]. Ohaja, E. (2003), Mass Communication Research and Project Writing. Lagos: John Letterman Ltd.

[19]. Okunna, S. Chinyere (2003). Ethics of mass communication, Enugu: NEW GENERATION BOOKS

[20]. Opitz, E. A. (1975). "Instinct and Ethics" in Okunna, S.C. (2003) Ethics of Mass Communication, Enugu: NEW GENERATION BOOKS

[21]. Patterson P. and Wilkins L. (2002), Media Ethics: Isues and Cases. New York: McGraw-Hill.

[22]. Ramírez, M.M. (2005). The radio journalist in Mexico: Practices, notions and attitudes toward professionalism. MA thesis, Cardiff School of Journalism.

[23]. Skjerdal, T.S. (2010). "Research on brown envelope journalism in the African media" African

[24]. Communication research, Vol. 3, No. 3, P 367 - 406

[25]. Soola, S.O. (1996) Cases of Unethical Practice in Some Nigerian Media. Ethics in Journalism:

[26]. Case Studies of Practice in West Africa. Accra: Ghana University Press

[27]. Surlin, S. A. (1987). "Value System Change by Students as a Result of Media Ethics Course"

[28]. Journalism quarterly, Summer - Autumn.

[29]. Uduokha, N. (2007). Communication and society. An unpublished lecture note. Department of Communication Arts, University of Uyo.

[30]. Wilson, D. (2010), Perspectives on Communication and Culture. Uyo: African Council for Communication Education (Nigeria chapter)

[31]. Wimmer, R. \& Dominic, J. (2000), Mass Media Research: An Introduction.Belmont, California: Wadsworth Publishing Company. 